\title{
The Efficiency Analysis of the Exhaust Air Heat Pump System
}

\author{
Alo Mikola, Teet-Andrus Kõiv \\ Department of Environmental Engineering, Tallinn University of Technology, Tallinn, Estonia \\ Email: alo.mikola@ttu.ee
}

Received 2 October 2014; revised 29 October 2014; accepted 16 November 2014

Copyright (C) 2014 by authors and Scientific Research Publishing Inc.

This work is licensed under the Creative Commons Attribution International License (CC BY). http://creativecommons.org/licenses/by/4.0/

(c) (i) Open Access

\begin{abstract}
This paper is based on long term parameter measurements of the exhaust air heat pumps (EAHP) system in a new built apartment building. The building was equipped with an exhaust air ventilation system and exhaust air heat pump for ventilation heat recover. The results of the measurements show that the COP of the EAHP is mainly related to the temperature graph of the heating system and the supply temperature of domestic hot water (DWH). During the measurement period some other impact factors, such as the quality of maintenance, the nighttime temperature graph of the heating system, the reduction of the exhaust air flows in case of low temperatures, mistakes in designing and low building quality, have also played a role. An analysis of energy consumption shows that in winter conditions the COP is about 3.0 and in the transition period about 3.3. The energy recovery value of the EAHP is 0.5 .
\end{abstract}

\section{Keywords}

Heat Pump, Exhaust Air Heat Pump, Heat Recovery, Heat Requirement, COP, The Coefficient of Performance

\section{Introduction}

The performance of residential ventilation systems plays an important role in good indoor air quality. At the same time the energy consumption of the ventilation systems is a considerable part of the energy consumption of the whole building. Although the main concept of exhaust air heat pumps (EAHP) was presented decades ago, recent studies show that in case of renovating the existing buildings it can remarkably reduce the energy consumption.

The issue of exhaust air heat recovery in apartment buildings has been topical since the 1970s. If an apartment 
building has been built with mechanical exhaust ventilation, the EAHP can be one of the best solutions for efficient heat recovery. Therefore, the EAHP has become a developing area in the heat pump market. A number of studies on the operation and re-engineering of the EAHP have been conducted. Today, the EAHP is widely used in the Nordic countries, especially in Sweden and Finland [1]-[4]. In Estonia, multi-storey apartment buildings constitute about $60 \%$ of the whole dwelling stock. The majority (75\%) of the apartment buildings were built primarily in 1961-1990 [5]. All these buildings are equipped with natural exhaust ventilation, which allows itself to be renovated into mechanical exhaust ventilation. One possible way to do that is to use EAHP systems.

In addition to the Nordic countries, EAHP systems have been studied elsewhere in Europe. They have also been studied in Italian climate conditions [6] [7]. The main focus of that study was on the work of the EAHP in the heating and cooling modes [8]. The Coefficient of Performance (COP) of the EAHP system is higher in case of low-energy buildings, which have definite peak loads. At the same time the study showed that the system cannot work without an additional electric heating coil. Studies in Sweden and Germany have shown that the heat pump as the heat exchanger in the air handling unit or in combination with conventional heat exchangers gives an average of $20 \%$ saving on the power consumption of an older building. In case of new buildings with a tighter envelope, the EAHP can cover $60 \%$ - $90 \%$ of the heat consumption [9].

A tight envelope is important to achieve higher efficiency of heat recovery. In the study by Heidt F.D. [10], it has been indicated that a building needs to have a tight envelope and that it should be possible to change the airflows in separate apartments. For maximal efficiency of the EAHP the heat should be given to the heating system and also to the domestic hot water system. In the same article it is assumed that the EAHP system is economically viable if the COP is higher than 4 . A higher COP is achievable if higher primary side and lower secondary side temperature graphs are used. The solution, in which the EAHP produces only domestic hot water, is not economically viable. The same conclusion is drawn in the Belgian study [11]. The higher is the temperature of the supply water in the domestic hot water system, the lower is the COP of the EAHP. Comparing the different heat sources it can be concluded that the heat pump reduces the $\mathrm{CO}_{2}$ emission if the $\mathrm{COP}$ value is higher than 2.4. At the same time the typical COP of the residential EAHP in Sweden is 3.1, which is 60\% of the ventilation air heating [12]-[16].

The EAHP systems for residential buildings have been studied most. For example, the Italian studies [13] [14] have shown that for high efficiency of the EAHP it is very important to install a well-functioning control system. The overall trend today is towards simple exhaust ventilation with an exhaust air heat pump for heat recovery and total heating. There are three major reasons for that:

1) The exhaust ventilation system only needs one fan and a less complicated duct system;

2) The EAHP can heat DHW as well as space;

3) The EAHP recovers two to three times more energy than the air-to-air heat exchanger;

4) The pressure in a building is always lower than outside, which minimizes the risk of vapor condensation in the walls-the risk of mould [12].

Some studies also include field measurements. In Sweden three exhaust air heat pumps [15] [16] were field monitored in the existing buildings in 2004-2005. Ground source heat pumps of the year 2003/04 were used in buildings with radiator systems constructed between 1950 and 1970. The results yielded an average SPF of the space heating system of 2.6, ranging between 2.4 - 2.9 for the five measured systems A-E. According to the field results of three exhaust air heat pumps, the SPF values are in the range of 1.4 - 1.7. The results were compared with simulations, where better building insulation and the best available technology had been used. The simulations show that with the current technology (the inverter heat pump) and passive house buildings, the SPF could be increased to about 2.6 [17].

The EAHP system can also be studied using different computer simulation programs. This way it is possible to quantify the improvements in SPF, Energy Coverage Factor, and general energy consumption attained by using BAT (inverter-controlled heat pumps, passive house technology, and low-energy household appliances) instead of the existing technology [17] [18]. In the same way simulation programs can be useful to analyse indoor air quality to find the best solutions for the mechanical exhaust ventilation system. For example, in the Swedish study [18], where the IDA-ICE simulation program was used, it was concluded that a low-temperature heating system with fresh air radiators does not cause deterioration in climate parameters. The same conclusion was also drawn from survey results. The simulation results of the economic analysis show that the payback period of the EAHP system can be shorter than in the case of the mechanical supply-exhaust system. 


\section{Method}

\subsection{Theory}

To assess the performance of the exhaust air heat pump in domestic hot water production as a ventilation heat recovery measure, compared to air to air heat exchanger technology, an equivalent heat recovery effectiveness $\varepsilon_{\text {eq }}$ Equation (1) is proposed. $\varepsilon_{\text {eq }}$ is defined as the ratio of the energy saving achieved by the exhaust air heat pump system in comparison with a reference system, converted to the heat losses in the heating system and ventilation

$$
\varepsilon_{\text {eq }}=\frac{f_{\text {ref }} \times Q_{\text {ref }}-f_{\mathrm{DHW}} \times Q_{\mathrm{DHW}}}{f_{\text {vent }}} \times Q_{\text {vent }},
$$

where $f$ is the conversion factor for the specific form of energy of the considered energy flux to heat in accordance with the chosen conversion framework. $Q$, gross energy use, is the product of the energy demand for that flux divided by its production efficiency [19].

Power consumption for air heating can be found in the following research methodology [20]. The specific heat loss $H \quad\left(\mathrm{~W} /{ }^{\circ} \mathrm{C}\right)$ for air heating can be calculated using Equation (2)

$$
H=L \times c \times r,
$$

where

$L$-airflow, $\mathrm{m}^{3} / \mathrm{s}$;

$c$ 一 specific heat of air, $\mathrm{kJ} /\left(\mathrm{kg} \cdot{ }^{\circ} \mathrm{C}\right)$;

$r$-air density, $\mathrm{kg} / \mathrm{m}^{3}$.

Heat consumption $Q$ (MWh) can be determined according to the heating degree days using Equation (3)

$$
Q=H \times S \times 24 \times 10^{-6} \times\left(1-\eta_{Q}\right),
$$

where

$S$ - the number of degree days, ${ }^{\circ} \mathrm{C} \cdot \mathrm{d}$;

$\eta_{\mathrm{Q}}$ - energy ratio of heat recovery.

In case of new built apartment buildings with the mechanical exhaust ventilation system the balance temperature of the heating period is $16^{\circ} \mathrm{C}$ and in the summer period $13^{\circ} \mathrm{C}$ [21].

The annual energy ratio of ventilation heat recovery can be calculated using Equation (3) [22]

$$
\eta_{Q}=1-Q_{s t} / Q \text {, }
$$

where

$Q_{\text {st }}$ —annual ventilation energy demand with heat recovery, MWh;

$Q$ —annual ventilation energy demand without heat recovery, MWh.

\subsection{The Studied Building}

The studied building is a new five-storey apartment building with 17 apartments, built in 2011. The building has a reinforced concrete bearing construction, the exterior wall panels are made of concrete and ash gas concrete, with $200 \mathrm{~mm}$ of insulation. The windows have wooden frames and double glazing. There is an automatically controlled central heating system. Ventilation has been solved with a central mechanical exhaust system from the sanitary rooms (toilets and bathrooms) and kitchens. Supply air is obtained through the fresh air valve installed in the windows. The warm air extracted from the sanitary rooms passes through the cooling batteries on the roof, which with a water glycol solution transfers its heat to the heat pump (see Figure 1) (the nominal rating of the heat pump is $17 \mathrm{~kW}$ ). The principle scheme of heat pump is shown in Figure 2. The heat pump gives the heat energy to the returning water of the heating system and to the domestic hot water.

\subsection{Measurements}

To study the work of the EAHP, the following parameters were measured: The electricity consumption of the EAHP, the domestic hot water production of the EAHP, the heat production of the EAHP to the heating system, 


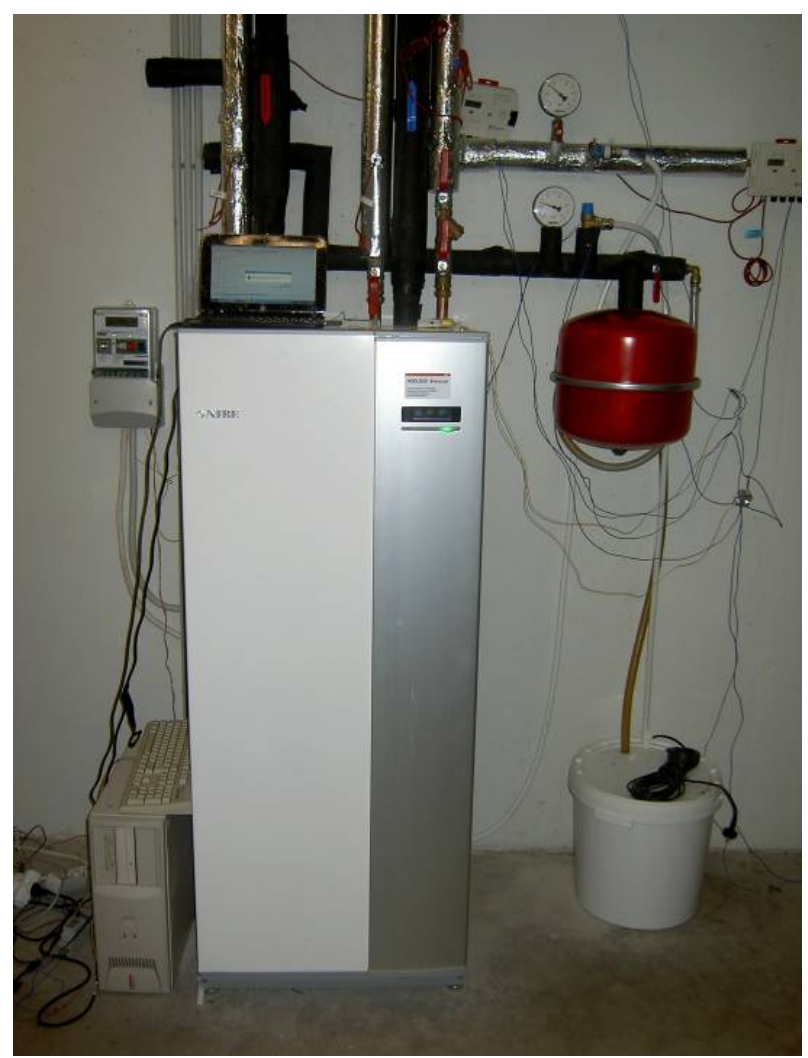

Figure 1. The heat pump in technical room of the building.

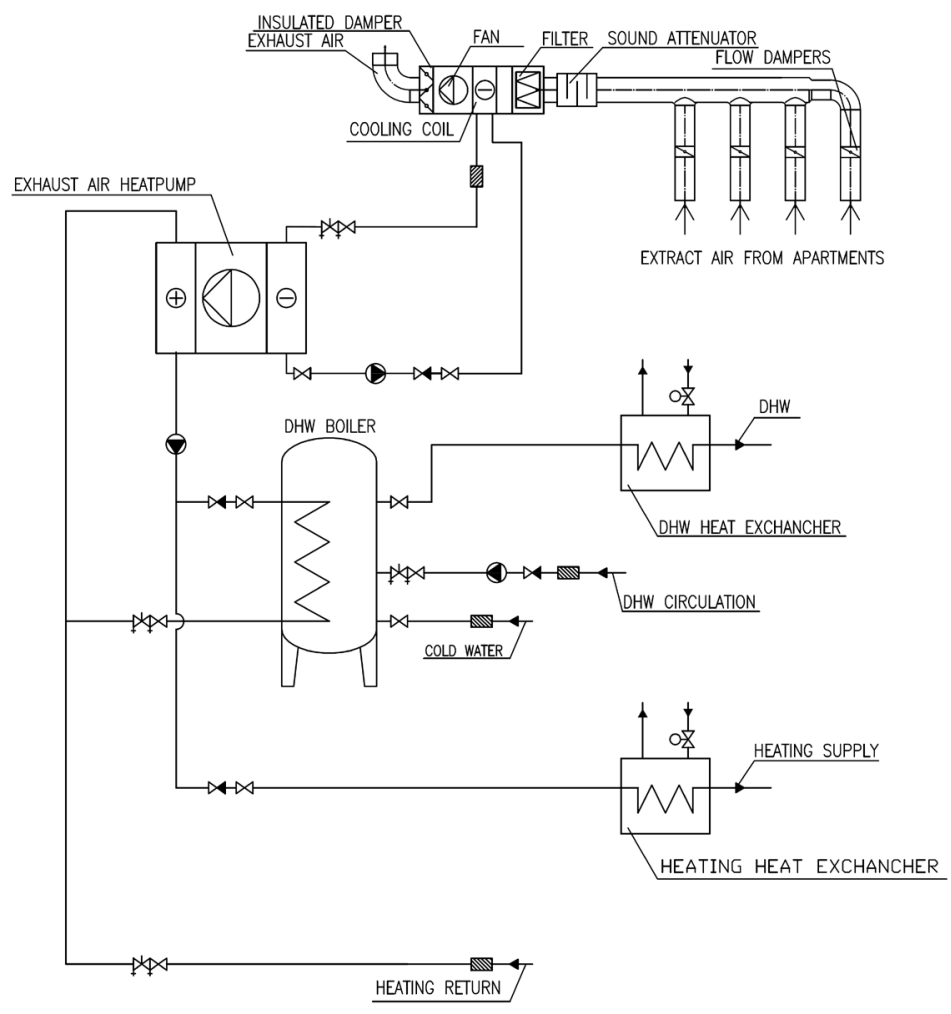

Figure 2. The principle scheme of the EAHP of an apartment building. 
domestic hot water consumption and district heat consumption. The measuring interval was 1 minute. For saving the data from loggers the Mbus outputs of the meters and a lap-top computer with DOKOM CS software were used. Separate loggers were mounted to measure the exhaust and extract air temperatures and also water temperatures in the boiler room. The exhaust air flow in the ventilation system was measured on the roof of the building. The structural scheme of the measurements is shown in Figure 3. The measurements were made during a 1-year period.

\section{Results}

The analysis of energy consumption shows that in winter conditions the COP is about $2.9-3.4$ and in the summer period about 3.0. The field measurements show that the energy recovery ratio of the real year is $\eta_{Q}=0.58$. If we assume that the EAHP works without problems, the theoretical energy recovery ratio would be close to $\eta_{\mathrm{Q}}=0.8$. Calculations were made using Equation (2), Equation (3) and Equation (4). As the outdoor climate is different during different years we have to use reference year climate. In Table 1 the energy consumption of the studied building is reduced to reference year and the proportion of EAHP and district heat are pointed out by month.

According to the measurements of the supply and return temperatures in the heating system it is possible to conclude that the nighttime temperature reduction program was used. From Figure 4 it can be assumed that the nighttime temperature reduction is approximately 3 degrees and the temperature is reduced from 22.00 till 6.00. Nighttime temperature reduction helps to increase the general COP of the EAHP system. We can also conclude that the real rated temperature graph of the heating system is $60 / 45^{\circ} \mathrm{C}$. As the designed temperature graph was $70 / 50$, the real graph is replaced with the lower one to increase the COP of the EAHP system. At the same time desirable indoor air temperature is achieved and night time temperature reduction does not influence the indoor air temperature too heavily. We can see from Figure 5 that the exhaust air temperature drops by about 1 degree.

To study the work of the EAHP system in the winter period, a 21-day period was chosen. In the selected period the heat pump system worked without problems. The results of the period are shown in Table 2 . The average outdoor air temperature of the chosen period was $-7^{\circ} \mathrm{C}$. It is possible to conclude that during a cold period the total EAHP production divides into 1/3 for DHW production and 2/3 for the heating water production.

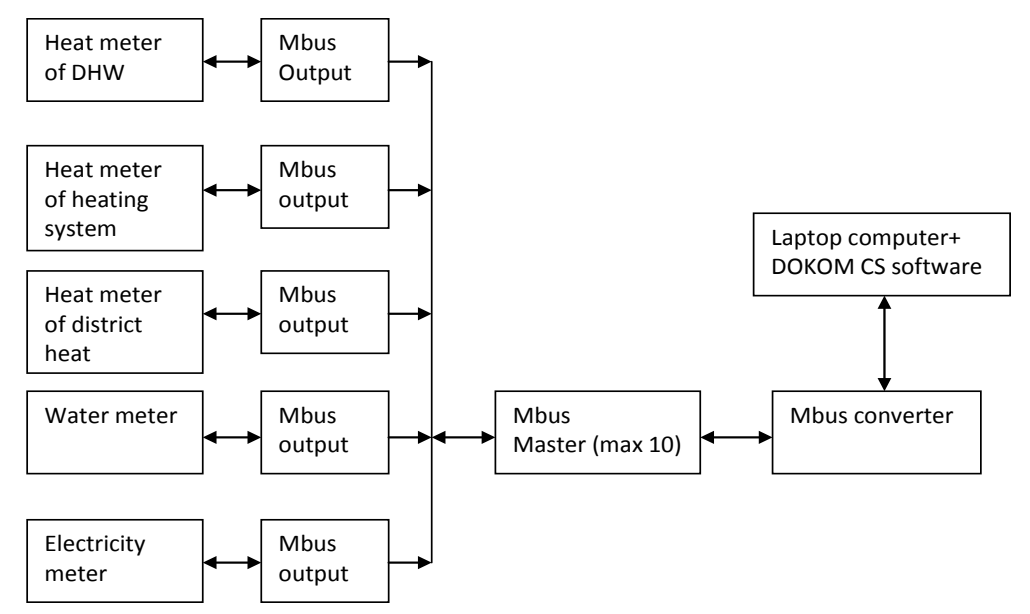

Figure 3. The structural scheme of the measurements.

Table 1. The energy consumption of the studied building by month (MWh).

\begin{tabular}{cccccccccccccc}
\hline Month & 1 & 2 & 3 & 4 & 5 & 6 & 7 & 8 & 8 & 10 & 11 & 12 \\
\hline Total consumption & 23.3 & 21.95 & 20.44 & 14.59 & 9.11 & 4.79 & 3.34 & 3.78 & 7.28 & 12.92 & 17.42 & 21.75 \\
District heat & 12.15 & 11.87 & 9.29 & 4.70 & 2.39 & 0.71 & 0.13 & 0.31 & 1.71 & 3.45 & 7.53 & 10.6 \\
EAHP to DHW & 3.4 & 3.07 & 3.4 & 3.29 & 3.4 & 3.0 & 3.0 & 3.0 & 3.0 & 3.4 & 3.29 & 3.4 \\
EAHP to heating system & 7.75 & 7.0 & 7.75 & 6.6 & 3.32 & 1.07 & 0.2 & 0.47 & 2.57 & 6.07 & 6.6 & 7.75 \\
\hline
\end{tabular}




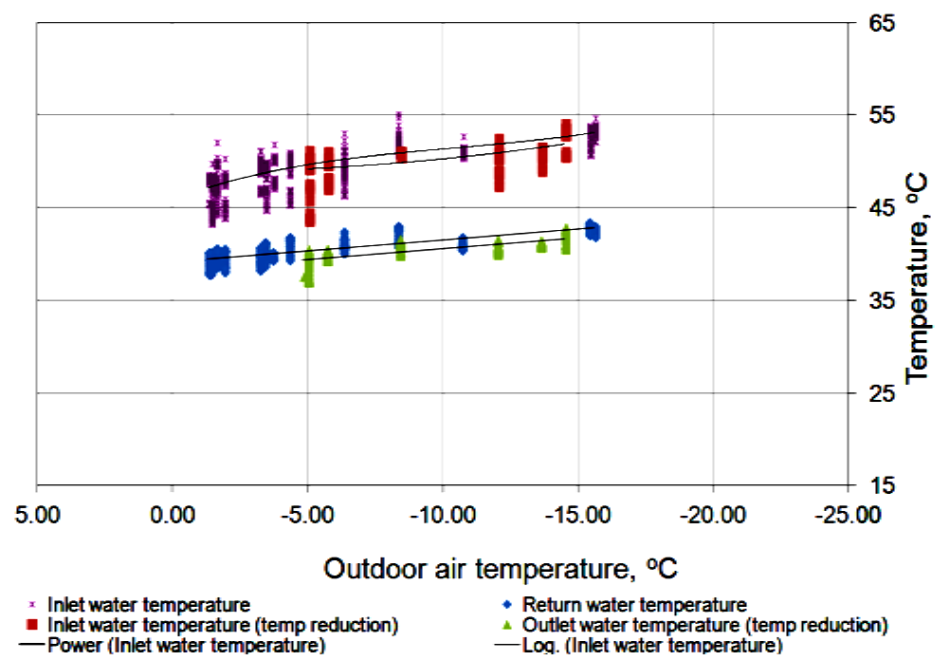

Figure 4. The supply and return liquid temperatures in the heating system and dependence on the outside air temperature.

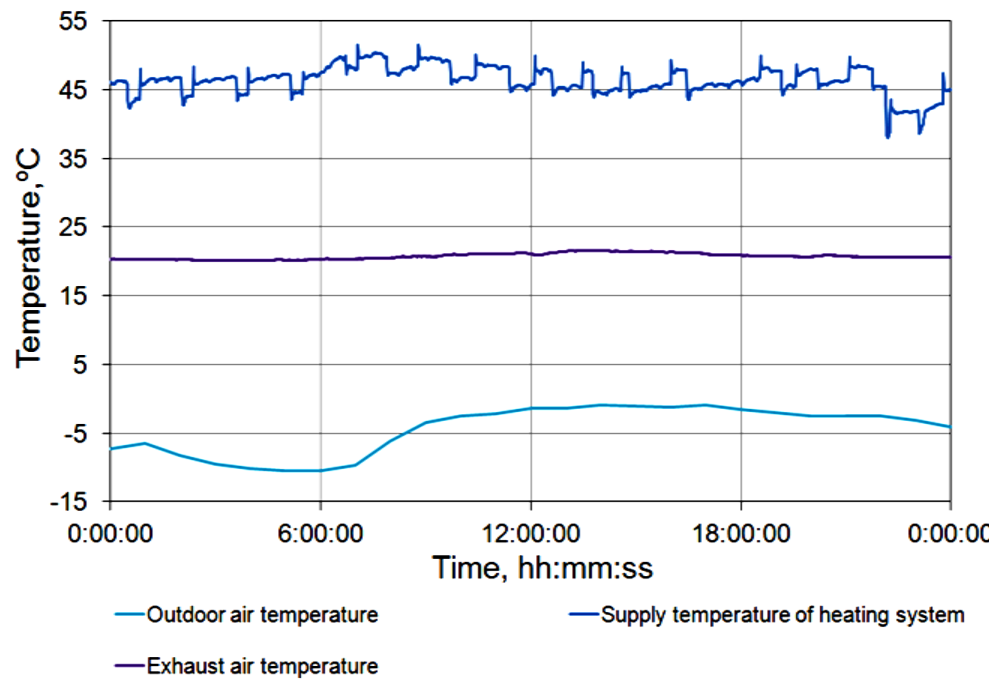

Figure 5. Main parameters of the EAHP.

Table 2. Energy consumption during a cold winter period (21 days).

\begin{tabular}{cccc}
\hline & Value & Unit & The share of heat production, \% \\
\hline District heat & 12.431 & MWh & MWh \\
EAHP electricity & 2.780 & MWh & MWh \\
EAHP heat production & 8.830 & MWh & 35.5 \\
EAHP heat to the heating system & 5.691 & - & - \\
EAHP to DHW & 3.139 & $\%$ & - \\
Ventilation heat recovery & 6.050 & $\%$ & - \\
COP of the studied period & 3.18 & 41.5 &
\end{tabular}


If we analyse the value of the COP of the EAHP according to the type of heat production, we can notice that during the heating period the COP is considerably higher. The instant values of COP in different heat pump modes are shown in Figure 6. In the winter period the average COP in the given conditions is 3 in the DWH production mode and 3.4 in the heating mode.

In summer the EAHP works with a lower COP than during the studied winter period. The main reason for this is the fact that in summer the EAHP works only in the DHW mode. We have already seen that if the system works in the DHW mode, the COP is lower even in the winter period. To study the work of the EAHP system in the winter period a 21-day period was chosen. During the selected period the heat pump system worked without problems. The results of the period are shown in Table 3.

If we analyse the value of the COP of the EAHP according to the type of heat production, we can notice that during the heating period the COP is considerably higher. The instant values of COP in different heat pump modes are shown in Figure 7. In the winter period the average COP in the given conditions is 3 in the DWH production mode and 3.4 in the heating mode.

\section{Conclusions}

This paper is based on long term parameter measurements of the EAHP system in a new built apartment building. The building was equipped with the exhaust air ventilation system and exhaust air heat pumps for ventilation heat recover. The results of the measurements show that the COP of the EAHP is mainly related to the

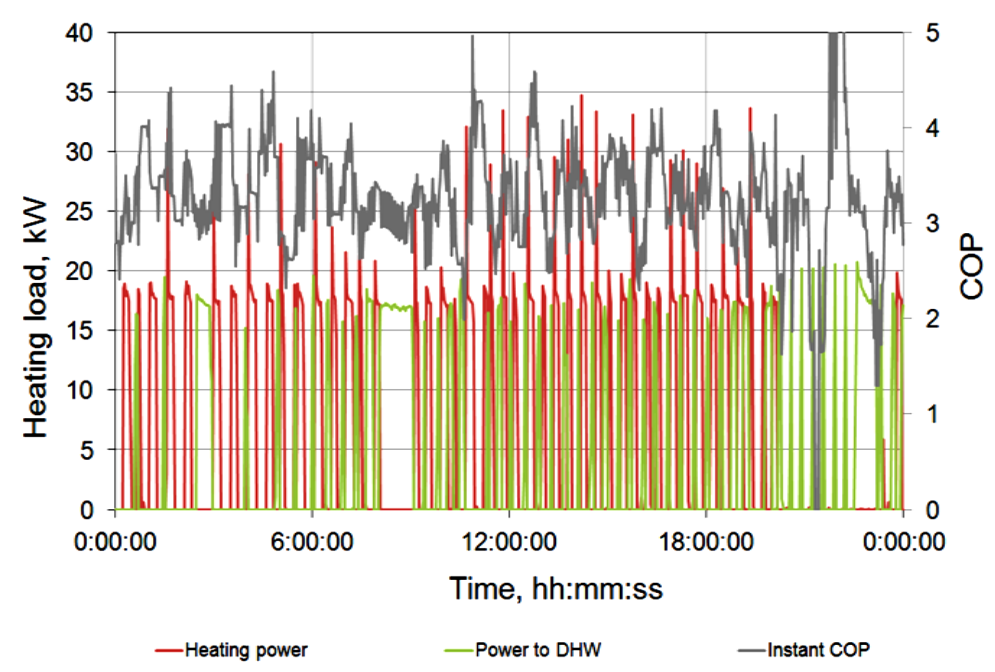

Figure 6. The instant COPs of the EAHP in the heating mode and in the DHW mode.

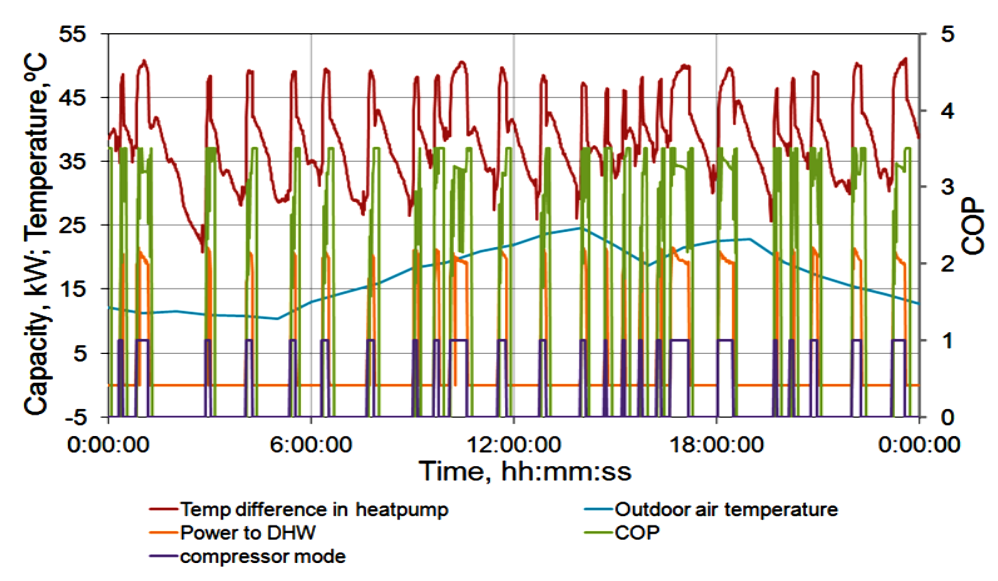

Figure 7. The instant COPs of the EAHP in the summer period. 
Table 3. Energy consumption during a warm summer period (30 days).

\begin{tabular}{cccc}
\hline & Value & Unit & The share of heat production, \% \\
\hline District heat & 0.316 & MWh & MWh \\
EAHP electricity & 0.614 & MWh & - \\
EAHP heat production & 1.904 & MWh & MWh \\
EAHP heat to the heating system & 0.012 & MWh & - \\
EAHP to DHW & 1.892 & - & - \\
Ventilation heat recovery & 1.290 & $\%$ & - \\
COP of the studied period & 3.10 & 85.8 &
\end{tabular}

temperature graph of the heating system and the supply temperature of domestic hot water (DWH). During the measurement period some other impact factors, such as the quality of maintenance, the nighttime temperature graph of the heating system, the reduction of the exhaust air flows in case of low temperatures, mistakes in designing and low building quality, have played a role. The analysis of energy consumption shows that in winter conditions the COP is about $2.9-3.4$ and in the summer period about 3.0.

When installing the exhaust air heat pump system in an old building, pre-conditions have to be met, without which it is not possible to ensure effective work of the system and indoor climate that satisfies requirements. The heating system of the building has to be adjusted to a low temperature heating graph, the recommended graphs are 55/40 or up to 60/40, because the heat pump works more effectively at a low temperature. There should be no towel dryers before the water extraction devices in the domestic hot water system, so that the hot water temperature would not have to be higher than $55^{\circ} \mathrm{C}$. The consumption analysis performed during a year showed that the exhaust air heat pump is able to produce heat according to the amount of exhaust air flow in these conditions (the air flow rate, indoor air temperature, heat transfer, efficiency of the device) producing heat pursuant to the amount of the exhaust air flow. The use of the exhaust air heat pump is more effective if, in addition to granting heat energy to the heating system, it can also be used for producing domestic hot water. In apartment buildings with the conventional mechanical exhaust ventilation system, the indoor climate is good. However, studies show that in those apartment buildings it is reasonable to use the exhaust air heat pump for energy conservation.

\section{Acknowledgements}

The research was supported by the Estonian Research Council, with institutional research funding grant IUT115, and with the project "Development of efficient technologies for the air change and ventilation necessary for the increase in the energy efficiency of buildings, AR12045", financed by SA Archimedes and by the project “Civil and Environmental Engineering PhD School, DAR9085".

\section{References}

[1] Eriksson, L., Masimov, T. and Westblom, S. (1986) Block of Flats with Controlled Natural Ventilation and Recovery of Heat. Swedish Council for Building Research.

[2] Liu, L.B., Fu, L. and Jiang, Y. (2010) Application of an Exhaust Heat Recovery System for Domestic Hot Water. Energy, 3, 1476-1481. http://dx.doi.org/10.1016/j.energy.2009.12.004

[3] Goorskey, S., Yang, G. and Smith, A. (2004) Home Energy Briefs: \#5 Water Heating. Rocky Mountain Institute.

[4] IEA Heat Pump Centre. Heat Pump in Residential and Commercial Buildings. IEA Heat Pump Centre, Sweden.

[5] Kalamees, T., Õiger, K., Kõiv, T.-A., et al. (2009) Technical Condition and Service Life of Estonian Apartment Buildings, Built with Prefabricated Concrete Elements. Tallinn University of Technology (in Estonian), 5.

[6] Fracastoto, G.V. and Serraino, M. (2010) Energy Analyses of Buildings Equipped with Exhaust Air Heat Pumps (EAHP). Energy and Buildings, 8, 1283-1289. http://dx.doi.org/10.1016/j.enbuild.2010.02.021

[7] Sakulpipantsin, P., Cauberg, J.J.M., van der Kooi, H.J. and Itard, L.C.M. (2007) Application of the Energy Concept to 
Ventilation Using Heat Recovery from Exhaust Air. Proceedings of Clima 2007 Well Being Indoors.

[8] Chauhan, R.B. (1985) Field Test on an Exhaust Air Heat Recovery Heat Pump. Division of Building Research, Ottawa.

[9] Johansson, D. (2009) The Life Cycle Costs of Indoor Climate Systems in Dwellings and Offices Taking into Account System Choice, Airflow Rate, Health and Productivity. Building and Environment, 2, 368-376. http://dx.doi.org/10.1016/j.buildenv.2008.03.011

[10] Heidt, F.D. (2006) Ventilation for Energy Efficient Buildings. ISES Summer Workshop.

[11] Fehrm, M., Reiners, W. and Ungemach, M. (2002) Exhaust Air Heat Recovery in Buildings. International Journal of Refrigeration, 4, 439-449. http://dx.doi.org/10.1016/S0140-7007(01)00035-4

[12] Nordtest Method (1990) Exhaust Air Heat Pumps: Performance. Finland.

[13] Berntsson, T. (2002) Heat Sources-Technology, Economy and Environment. International Journal of Refrigeration, 4, 428-438. http://dx.doi.org/10.1016/S0140-7007(01)00034-2

[14] Sakellari, D. and Lundqvist, P. (2004) Energy Analysis of a Low-Temperature Heat Pump Heating System in a SingleFamily House. International Journal of Energy Research, 1, 1-12. http://dx.doi.org/10.1002/er.947

[15] Sakellari, D. and Lundqvist, P. (2005) Modelling and Simulation Results for a Domestic Exhaust-Air Heat Pump Heating System. International Journal of Refrigeration, 7, 1048-1056. http://dx.doi.org/10.1016/j.ijrefrig.2005.03.007

[16] Johansson, D. (2007) The Cost of Indoor Climate Systems in Dwellings Taking into Account Airflow Rate, Health and Productivity. Proceedings of Clima 2007 Well Being Indoors.

[17] Karlsson, F., Axell, M. and Fahlen, P. (2003) Heat Pump Systems in Sweden—Country Report for IEA HPP Annex 28. Energy Technology, Bor'as.

[18] Berg, J.M., Ruud, H.S, Lindberg, U., Stenlund, M. and Axell, M. Exhaust Air Heat Pumps—Results from a Field Study in Sweden.

[19] Laverge, J., Cuyper, A.D. and Arnold, J.A. (2013) Equivalent Heat Recovery Effectiveness of Exhaust Air Heat Pumps. Proceedings of CLIMA 2013, 11th REHVA World Congress and the 8th International Conference on Indoor Air Quality, Ventilation and Energy Conservation in Buildings, Prague.

[20] EVS-EN 15450:2007 (2007) Heating Systems in Buildings—Design of Heat Pump Heating Systems. Estonian Centre for Standardisation.

[21] Kõiv, T.-A. and Rant, A. (2013) Hoonete Küte. TTÜ Kirjastus, Tallinn.

[22] Abel, E. and Voll, H. (2010) Hoonete energiatarve ja sisekliima. Presshouse, Tallinn. 
Scientific Research Publishing (SCIRP) is one of the largest Open Access journal publishers. It is currently publishing more than 200 open access, online, peer-reviewed journals covering a wide range of academic disciplines. SCIRP serves the worldwide academic communities and contributes to the progress and application of science with its publication.

Other selected journals from SCIRP are listed as below. Submit your manuscript to us via either submit@scirp.org or Online Submission Portal.
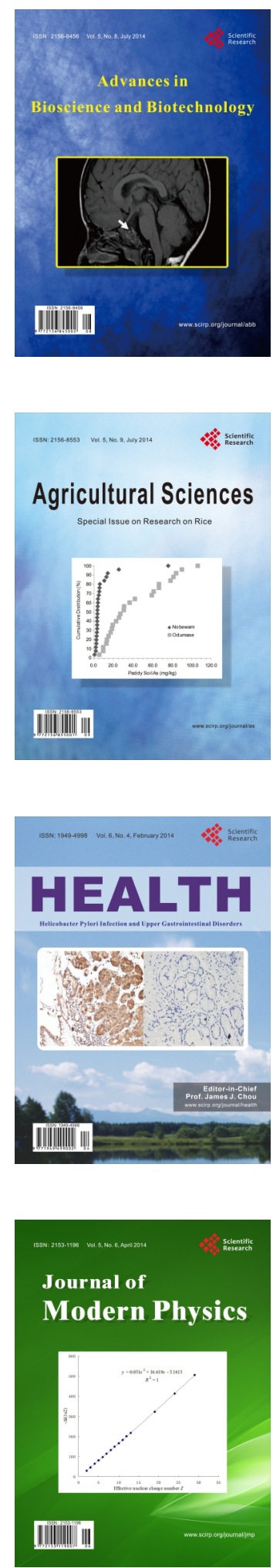
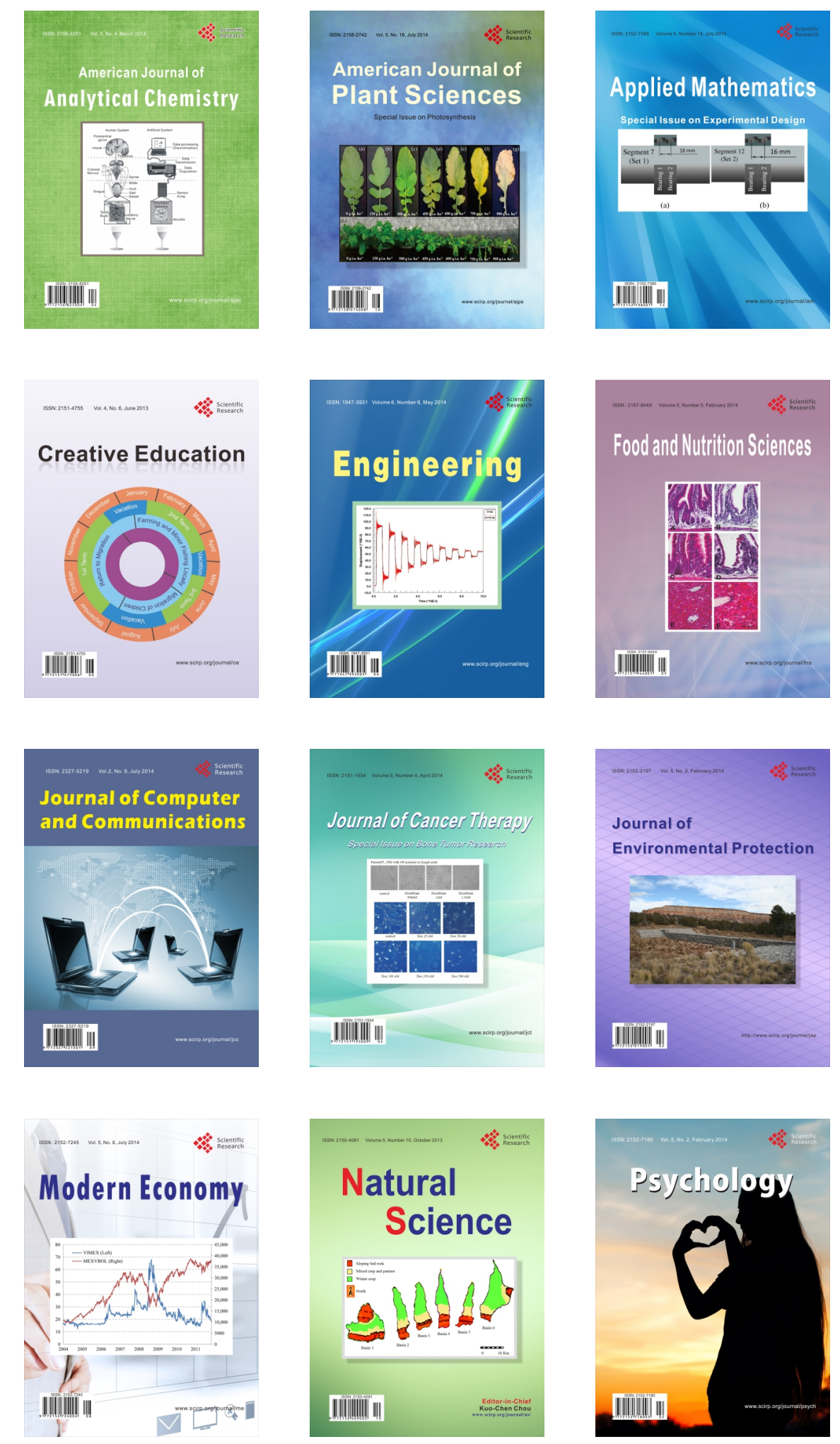